\title{
AJRC
}

Australia - Japan Research Centre

\section{Innovation in the Service Sector and the Role of Patents and Trade Secrets*}

\section{AJRC Working Paper 03/2014 June 2014}

\section{Masayuki Morikawa}

Research Institute of Economy, Trade \& Industry (RIETI)

\section{Abstract}

This paper, using Japanese firm-level data, presents findings about innovative activities in the service sector and the role of patents and trade secrets on innovation. According to the analysis, first, service firms have fewer product innovations than do manufacturing firms, but the productivity of innovative service firms is very high. Second, service firms have a low propensity for holding patents, but their holding of trade secrets is comparable to that of the manufacturing firms. Third, patents and trade secrets have positive relationships with product innovations, and the effects are quantitatively similar in magnitude in both the manufacturing and the service sectors. On the other hand, a positive relationship between trade secrets and process innovations is found only in the manufacturing sector. These results suggest a pivotal role of the law protecting trade secrets on innovation and productivity growth in the service sector. 
*I would like to thank Masahisa Fujita, Ippei Fujiwara, Isamu Yamauchi and the seminar participants at RIETI for their helpful comments and suggestions. Any errors are my own. I would like to thank the Ministry of Economy, Trade and Industry for providing the micro data of the Basic Survey of Japanese Business Structure and Activities employed in this study. This research is supported by the JSPS Grants-in-Aid for Scientific Research (B, 23330101).

\section{Keywords}

Innovation; Service sector; Patent; Trade secret

\section{JEL Classification}

O31; O34; L80

\section{Suggested Citation}

Morikawa, M., 2014. Innovation in the Service Sector and the Role of Patents and Trade Secrets, AJRC Working Paper No.3/2014, June. Australia-Japan Research Centre, Crawford School of Public Policy, The Australian National University.

This paper is also available at the RIETI website.

\section{Address for correspondence \\ (E) ajrc@anu.edu.au}

ISSN 07288409

ISBN 978-0-86413-002-0

The Australia-Japan Research Centre (AJRC) conducts research to explore and improve understanding of the economies and economic policy processes in Australia and Japan and both countries' strategic interests in the Asia Pacific economy.

The AJRC Working Paper Series aims to provide a forum for the exchange of topical research and contains the latest research and analysis on the Japanese economy, as well as the political economy, regional integration and trade. The views expressed in AJRC Working Papers are those of the individual authors and do not represent the views of the Australia-Japan Research Centre, the Crawford School, or the institutions to which authors are attached.

The Crawford School of Public Policy is the Australian National University's public policy school, serving and influencing Australia, Asia and the Pacific through advanced policy research, graduate and executive education, and policy impact. 


\section{Introduction}

This paper, using Japanese firm-level data, empirically analyzes innovation activities in the service sector and the role of patents and trade secrets on innovation. In advanced countries, including Japan, service industries account for more than 70\% of GDP, and improving their productivity is the key to increasing the growth potential for the entire economy. While there are a variety of factors affecting the productivity of industries and firms, innovation is one of the significant determinants of productivity growth. However, innovation in the service industry has not been subjected to sufficient empirical analysis in Japan or in other advanced economies. ${ }^{1}$ We present novel findings about innovations of service firms in comparison with those of manufacturing firms.

Generally speaking, formal R\&D investments are active among manufacturing firms compared with firms in the service industry. According to the Basic Survey of Japanese Business Structure and Activities (Ministry of Economy, Trade and Industry: METI) in 2011, the mean R\&D intensity (R\&D expenditure/sales) of service firms is $0.34 \%$, which is about a third of the figure for manufacturing firms $(1.03 \%){ }^{2}$ However, innovation is not limited to development of new products/services through formal R\&D investments. According to the current guidelines for internationally comparable innovation surveys, "innovation” includes 1) product, 2) process, 3) organizational, and 4) marketing innovations (OECD, 2005). The Japanese Innovation Survey 2012 (National Institute of Science and Technology Policy: NISTEP, 2014) indicates that the percentages of firms that made these four types of innovations during the past three years are 1) 15.8\% (new businesses), 2) 15.6\% (new products/services), 3) $28.3 \%$ (products/services improvement), and 4) $22.5 \%$ (new production/delivery method), respectively: innovations other than product innovation are more frequent. ${ }^{3}$ Although the R\&D intensity of service firms, on average, is lower than that of manufacturing firms, these broadly defined innovations may play important roles for productivity improvements of the service industry. In fact, recent productivity studies argue that we should focus more on "soft innovations" related to human resources, organizational

\footnotetext{
${ }^{1}$ While a large number of empirical studies on innovation focus on the manufacturing industry, several papers have dealt with innovations in the service industry. Recent examples include Musolesi and Huiban (2010), Leiponen (2012), Basker (2012), and Bartelsman et al. (2013).

${ }^{2}$ The service industries of the figures are wholesale, retail, and narrowly-defined service industries (business services and personal services). The calculation of the mean figures includes non-R\&D-performing firms.

${ }^{3}$ According to the report of the Survey, the percentages of firms engaged in these four types of innovations are smaller than those in Germany and France.
} 
change, and other intangible investments in analyzing innovations in the service sector (Jorgenson and Timmer, 2011; Timmer et al., 2011).

Under these circumstances, we present empirical findings about innovative activities of the service sector in comparison with those of the manufacturing sector by focusing on the role of patents and trade secrets on innovations.

In Japan, patents and trade secrets are protected by the Patent Act and the Unfair Competition Prevention Act, respectively. The requisites for information to be legally protected as trade secret are that 1 ) the information is the subject of reasonable efforts to maintain its secrecy, 2) the information has economic value, and 3) the information is not known to the general public. Trade secrets are not limited to technological information such as manufacturing know-how. Non-technological information, such as customer lists, recipes of restaurants, manuals of sales or services, and contract information, can be protected as trade secrets. These types of non-technological information are often possessed by firms in the service sector. The Unfair Competition Prevention Act has been amended several times to strengthen the protection of trade secrets. To be legally protected by the Unfair Competition Act, it is desirable for firms to document a "Trade Secret Management Rule" in accordance with the "Guideline of Trade Secret Management” (Ministry of Economy, Trade and Industry).

Levin et al. (1987) is a representative study analyzing firms' choice of appropriation mechanisms of innovation based on a survey for R\&D-conducting manufacturing firms in the U.S. They indicate that appropriation mechanisms other than patent filing, such as secrecy and lead time, play important roles. Arundel (2001) analyzes the relative importance of secrecy and patents, using data from the 1993 European Community Innovation Survey, and indicates that a large number of European manufacturing firms, especially smaller firms, rates secrecy as more valuable than patents. In Japan, Goto and Nagata (1997) conduct a similar survey for Japanese manufacturing firms and compare the results with those of U.S. firms. According to their study, the percentage of Japanese firms choosing secrecy as a mechanism for appropriation is far smaller than the figure found in the U.S. While the subjects of these studies are limited to manufacturing firms, Amara et al. (2008) conducted a similar analysis for knowledge-intensive business service (KIBS) firms in Canada. They show that the importance of patents as an appropriation mechanism is lower among these firms and that there is a complementarity between patents and secrecy. Yamauchi et al. (forthcoming), using data from the Survey on Research Activities of Private Corporations (NISTEP) in 2011, analyze the relative importance of appropriation measures. While most of the sample firms are in the manufacturing industry, a small number of non-manufacturing firms are included in the sample. They show that Japanese firms have become more 
dependent on secrecy in comparison with the past study of Goto and Nagata (1997) and that the relative importance of secrecy is higher among SMEs than large firms. Overall, these studies have made clear the use of various appropriation measures, but the difference between manufacturing and service firms has not yet been fully analyzed. ${ }^{4}$

Against these backgrounds, this paper, using an original firm survey linked with government statistics, presents empirical findings about innovative activities in the service sector and the role of patents and trade secrets on innovations by paying attention to the differences from the manufacturing sector. The novelty of this paper is, first, that our data covers a large number of service firms, which enables us to compare the differences between manufacturing and service industries. Second, innovations of this paper include not only product and process innovations but also improvements in existing products/services and entry into new businesses. Third, we use an accurate objective measure of holding trade secrets by utilizing information of whether the firm has the "Trade Secret Management Rule.”

The major findings of this paper can be summarized as follows. First, service firms have fewer product innovations than do manufacturing firms, but the productivity of innovative service firms is very high. Second, service firms have a low propensity of holding patents, but the holding of trade secrets is comparable to that of manufacturing firms. Third, patents and trade secrets have positive relationships with product innovations, and the effects are quantitatively similar in magnitude both in manufacturing and service sectors. On the other hand, a positive relationship between trade secrets and process innovations is found only in the manufacturing sector.

The rest of this paper is structured as follows. Section 2 explains the method of analysis and the data used in this paper. Then, Section 3 reports and interprets the results. Finally, Section 4 concludes with policy implications.

\section{Data and Methodology}

This paper uses cross-sectional micro data in fiscal year 2011 from the Survey of Corporate Management and Economic Policy (Research Institute of Economy, Trade and Industry: RIETI) linked with the Basic Survey of Japanese Business Structure and Activities (METI). The Survey of Corporate Management and Economic Policy is an original survey conducted

\footnotetext{
${ }^{4}$ Hall et al. (2012) present an excellent survey of empirical studies on the protection measures of technological information. Rockett (2010) surveys theoretical analyses on the relationship between patent and secrecy.
} 
by RIETI from December 2011 to February 2012. The questionnaire was sent to 15,500 Japanese firms covering manufacturing and service firms spanning from large, medium, to small sized firms, and a total of 3,444 firms responded to the survey (the response rate was 22.2\%). The survey questionnaires include managerial objectives, composition of shareholders, internal organization, innovations, and business restructuring. In this paper, we use questions about the innovative activities and the existence of the Trade Secret Management Rule of the firms. Specifically, the surveys asked respondents to indicate the innovative activities that they engaged in during the last three years from a list of the following four activities: 1) entry into new businesses; 2) development of new products/services; 3) improvement of existing products/services; and 4) adoption of new production or delivery methods. Roughly speaking, activities 2) and 3) correspond to product innovation, and activity 4) corresponds to process innovation. The specific question about trade secrets is, "Does your firm establish the Trade Secret Management Rule to protect technology and know-how important for your business?” If the answer is “yes,” we can infer that the firms have trade secrets with economic value.

The Basic Survey of Japanese Business Structure and Activities, an annual survey begun in 1992, is a representative set of government statistics on Japanese firms with 50 or more regular employees, including those engaged in mining, manufacturing, electricity and gas, wholesale, retail, and several service industries. The purpose of this survey is to capture a comprehensive picture of Japanese firms, including their basic financial information (sales, costs, profits, book value of capital, etc.), the number of employees, R\&D expenditure, IT usage, and foreign direct investment. In this paper, we use data from the Survey for the fiscal year 2011 (conducted in 2012). The survey items used in this paper include industry classification, number of employees, year of establishment, holding of patents, and R\&D expenditure. In addition, financial information, including sales, labor cost, and book value of tangible assets, are employed for the estimation of total factor productivity (TFP).

Although the number of patent holdings is available from the Basic Survey of Japanese Business Structure and Activities, the data on trade secrets in the Survey of Corporate Management and Economic Policy is limited to whether the firm has trade secrets. Therefore, we treat both patent and trade secret holdings as discrete (dummy) variables to ensure the comparability of the relative importance of these two appropriation mechanisms of intellectual properties.

After linking these two data sets at the firm level, we first test the significant difference between manufacturers and service firms regarding the percentages of firms engaged in innovative activities, holding patents, and holding trade secrets. In relation to these tests, we compare the mean TFP levels of firms with and without the four innovative activities. The 
service firms in our data set are the firms whose industries are classified as wholesale, retail, and the narrowly defined service industries (business services and personal services). Next, we analyze the relationship between intellectual property holdings and innovative activities. Specifically, we conduct simple probit analysis where the four innovative activities mentioned above are used as dependent variables and the holdings of patents (patent) and trade secrets (secret) are used as the main explanatory variables (equation (1)). In these estimations, firm size (natural logarithms of regular employees), firm age, and industry dummies (1 digit) are used as control variables. In addition to the estimation for the full sample, separate estimations for the subsamples of manufacturing and service firms are conducted.

$$
\begin{aligned}
\operatorname{Pr}(\text { innovation }=1)= & F\left(\beta_{0}+\beta_{1} \text { patent }+\beta_{2} \text { secret }+\beta_{3} \text { firm size }+\beta_{4}\right. \text { firm age } \\
& \left.+\beta_{5} \text { industry dummies }\right)+\varepsilon
\end{aligned}
$$

The interest here is the statistical significance and the size of the coefficients for patent $\left(\beta_{1}\right)$ and trade secret $\left(\beta_{2}\right)$. In addition to the baseline estimation, we add an interaction term of patents and trade secrets as an explanatory variable (equation (2)). The purpose of this additional estimation is to detect a complementary role of patents and trade secrets in innovation. If the estimated coefficient for the interaction term $\left(\beta_{3}\right)$ is positive, complementary holding both patents and trade secrets enhances the probability of innovation.

$$
\begin{aligned}
\operatorname{Pr}(\text { innovation }=1)= & F\left(\beta_{0}+\beta_{1} \text { patent }+\beta_{2} \text { secret }+\beta_{3} \text { patent } * \text { secret }+\beta_{4}\right. \text { firm size } \\
& \left.+\beta_{5} \text { firm age }+\beta_{6} \text { industry dummies }\right)+\varepsilon
\end{aligned}
$$

The number of sample firms is 3,444. Among the sample, manufacturing and service firms comprise 1,567 and 1,860 , respectively. ${ }^{5}$ Summary statistics of the major variables are presented in Table 1.

\section{Results}

Table 2 shows the percentages of firms engaged in innovative activities during the last three years and the t-test results for the significant differences between industries. Among the four types of innovative activities, the percentages of firms engaged in the development of new

\footnotetext{
${ }^{5}$ The remaining 17 firms are classified in other industries such as mining and construction. The actual number of firms used in the analysis is about 3,000, which responded to the relevant questions.
} 
products/services are the highest, followed by the improvement of existing products/services, both for manufacturing and service firms. The figures are higher among manufacturing firms than service firms by $12 \%$ to $13 \%$ points (statistically significant at the $1 \%$ level), indicating that manufacturing firms are more active in product innovations. In contrast, entry into new businesses is more prevalent among service firms than manufacturing firms: the difference between industries is statistically significant at the $1 \%$ level. The figures for adoption of new production or delivery methods are significantly higher for manufacturing firms, but the size of the difference is relatively small. Overall, manufacturing firms are more active both for product and process innovations in comparison with service firms, suggesting that the relatively fewer innovations may be a cause of low productivity growth of the service industry.

Next, we compare the mean TFP levels of firms with and without the four types of innovative activities. The TFP is calculated by employing data from the Basic Survey of Japanese Business Structure and Activities in a nonparametric manner that uses a hypothetical representative firm as a reference. This is called the index number method, which has often been used for TFP measurement in recent studies (see, for example, Nishimura et al., 2005; Fukao and Kwon, 2006; Morikawa, 2010, 2013). Specifically, the input and output of a hypothetical representative firm are calculated as the geometric means of those of all firms, and the cost shares of labor and capital are calculated as arithmetic means. The TFP for each firm is calculated relative to the hypothetical representative firm. The cross-tabulation results are presented in Table 3, which shows the TFP level of innovators and non-innovators with t-test statistics of the differences. For the full sample (Table 3 (1)), TFP of the firms that developed new products/services and the firms that improved existing products/services are $6.1 \%$ points and $8.7 \%$ points higher, respectively, than those without these activities. Because the data used in this paper is cross-sectional, the results do not necessarily indicate causal relationships. However, the results suggest that product innovations are strongly related to productivity at the firm level. ${ }^{6}$ While entry into new businesses and adoption of new production or delivery methods (process innovation) are also related to higher TFP levels, the differences are statistically insignificant.

Looking at the separate figures for the subsamples of manufacturing and service firms, the positive and significant relationships between product innovations and TFP are observed for both sectors (Table 3 (2) and (3)). However, interestingly, the difference in TFP with or without product innovations is larger among service firms. In the service sector, the mean TFP level of the firms that developed new services is $11.7 \%$ higher than the firms without such

\footnotetext{
${ }^{6}$ Hall (2011), using a survey on the relationship between innovation and productivity, points out that product innovation has substantial positive impacts on productivity, but that the impacts of process innovation on productivity is ambiguous.
} 
activity (the comparable figure is $5.6 \%$ for manufacturing firms). On the other hand, process innovation-improvement of existing products/services-has a positive and significant relationship with TFP only among manufacturing firms (the difference is 9.1\%), and the relationship is insignificant among service firms.

Table 4 shows the percentages of firms holding patents or trade secrets and the t-test results for the significant differences between industries. The percentages of firms holding patents are $39.2 \%$ for manufacturing firms and 9.8\% for service firms: a large and statistically significant difference is found. On the other hand, the percentages of firms holding trade secrets are $33.0 \%$ and $32.6 \%$ for manufacturing firms and service firms, respectively: the figures are very close to each other, and the difference is statistically insignificant. These patterns suggest that trade secrets are relatively important appropriation measures of intellectual property in the service sector. Panels B and C of Table 4 are the separate calculations for R\&D-performing and non-R\&D-performing firms. R\&D-performing firms of this table are defined as firms with positive R\&D expenditures during the fiscal years 2009 and 2011. 53.2\% (=746/1,402) of manufacturing firms conduct R\&D investment, but the figure is only $17.3 \%(284 / 1,640)$ for firms in the service industry: confirming that a relatively small number of service firms conducts formal $R \& D$. To restrict the sample to $R \& D$-performing firms, the percentage of firms holding patents is higher in the manufacturing industry, but the percentage of firms holding trade secrets is higher in the service industry (the differences are statistically significant at the $1 \%$ level).

Probit estimation results of the equation (1) are presented in Table 5, where the four types of innovations are used as dependent variables. The figures indicate the marginal effects with robust standard errors in parentheses. The estimated coefficients for the control variables (firm size and firm age) are not reported in this table. For the full sample, the coefficient for patent is positive and statistically significant both for the development of new products/services and the improvement of existing products/services (Panel B and C of Table 5 (1)). After controlling for firm size, firm age, and industry, firms with patents are $25.2 \%$ and $13.3 \%$ more likely to be engaged in these two types of product innovations, respectively. The coefficient for secret is positive and statistically significant for all of the four types of innovations. Firms with trade secrets are 3.1\% (new businesses), 8.4\% (new products/services), 10.5\% (products/services improvement), and 5.4\% (new production or delivery methods) more likely to innovate.

Columns (2) and (3) show the results for the subsamples of manufacturing and service firms, respectively. Regarding the product innovations (panels $\mathrm{B}$ and $\mathrm{C}$ ), the coefficients for patent and secret are positive and significant both for manufacturing and service firms, and the sizes of the coefficients are somewhat larger for manufacturing firms. For other types of innovations, the coefficients for patent are insignificant both for manufacturing and service 
firms, and the coefficients for secret are positive and significant only for manufacturing firms. In particular, the marginal effect of trade secrets for the process innovation of manufacturing firms (panel D) is relatively large (9.5\%): similar in magnitude to that of the development of new products.

To interpret the above results from the viewpoint of innovation in the service industry, holding patents and trade secrets plays an important role for the innovative activities of service firms, especially for their product innovations. Although the size of the coefficient is larger for patents than for trade secrets, the number of firms holding patents is very small among service firms (Table 4). That is, in comparison with the manufacturing industry, trade secrets are a relatively important appropriation mechanism in the service industry.

Finally, we report estimation results of equation (2), where the interaction term of patent and secret is used as an additional explanatory variable. For the full sample, the coefficient for the interaction term is positive and significant only for the development of new products/services (panel B, Table 6 (1)). However, separate estimations for manufacturing and service subsamples reveal that the coefficient for the interaction term is significant only among manufacturing firms (Table 6 (2)). The result suggests a complementary role of patents and trade secrets for the product innovation of the manufacturing industry, but such a relationship is not observed for innovations in the service industry.

\section{Conclusion}

This paper, using an original firm survey linked with government statistics, presents empirical findings about innovative activities in the service sector and the role of patents and trade secrets on innovations by focusing on the differences with the manufacturing sector.

We have detected a variety of distinct characteristics of innovation activities among service firms. First, service firms have fewer product innovations than do manufacturing firms, but the TFP of innovative service firms is very high. Second, service firms have a low propensity for holding patents, but the holding of trade secrets is comparable to that of the manufacturing firms, suggesting the importance of knowledge and know-how, which are difficult to patent, for the innovation in service sector. Third, patents and trade secrets have positive relationships with product innovations, and the effects are quantitatively similar in magnitude both in the manufacturing sector and in the service sector. On the other hand, a positive relationship between trade secrets and process innovations is found only in the manufacturing sector. Finally, a complementary role of patents and trade secrets is detected only for product innovation in the manufacturing sector. 
The findings that the innovative service firms exhibit high productivity and that the holding of intellectual properties is strongly related to innovations in service firms suggest that the law protecting trade secrets contributes to productivity growth in the service sector. However, whether the current legal system regarding intellectual property is sufficient for promoting soft innovations specific to the service industry should be studied further.

While this paper presents new findings on the difference in innovations between the manufacturing and service industries, some reservations should be mentioned. Because the results of this paper depend entirely on a cross-sectional data set, the detected relationships cannot be interpreted as causal ones. For example, the positive relationship between holding intellectual properties and innovations can be interpreted as indicating that the innovative firms are more active in protecting their intellectual properties. In addition, we cannot eliminate a possible omitted variable bias that some unobservable firm characteristics-for example, management quality or the skill of managers - may affect both the holdings of patents/trade secrets and the innovativeness of the firms. However, it should be stressed that the purpose of this paper is to provide understudied facts about the innovation of service firms and its relationship with intellectual property. To deepen our understanding on service innovation, it is desirable to accumulate panel data for innovations and intellectual property rights covering a large number of service firms. 
References

Amara, Nabil, Rejean Landry, and Namatie Traore (2008), "Managing the Protection of Innovations in Knowledge-Intensive Business Services,” Research Policy, Vol. 37, No. 9, pp. 1530-1547.

Arundel, Anthony (2001), "The Relative Effectiveness of Patents and Secrecy for Appropriation,” Research Policy, Vol. 30, No. 4, pp. 611-624.

Bartelsman, Eric, Sabien Dobbelaere, and Bettina Peters (2013), “Allocation of Human Capital and Innovation at the Frontier: Firm-Level Evidence on Germany and the Netherlands,” IZA Discussion Paper, No. 7540.

Basker, Emek (2012), "Raising the Barcode Scanner: Technology and Productivity in the Retail Sector,” American Economic Journal: Applied Economics, Vol. 4, No. 3, pp. 1-27.

Cohen, Wesely M., Richard R. Nelson, and John P. Walsh (2000), "Protecting Their Intellectual Assets: Appropriability Conditions and Why U.S. Manufacturing Firms Patent (or Not),” NBER Working Paper, No. 7552.

Fukao, Kyoji and Hyeog Ug Kwon (2006), "Why Did Japan's TFP Growth Slow Down in the Lost Decade? An Empirical Analysis Based on Firm-Level Data of Manufacturing Firms,” Japanese Economic Review, Vol. 57, No. 2, pp. 195-228.

Goto, Akira and Akiya Nagata (1997), "Technological Opportunities and Appropriating the Returns from Innovation: Comparison of Survey Results from Japan and the U.S.” NISTEP Report, No. 48.

Hall, Bronwyn H. (2011), “Innovation and Productivity,” NBER Working Paper, No. 17178.

Hall, Bronwyn H., Christian Helmers, Mark Rogers, and Vania Sena (2012), “The Choice between Formal and Informal Intellectual Property: A Literature Review,” NBER Working Paper, No. 17983.

Jorgenson, Dale W. and Marcel P. Timmer (2011), "Structural Change in Advanced Nations: A New Set of Stylised Facts,” Scandinavian Journal of Economics, Vol. 113, No. 1, pp. 1-29.

Leiponen, Aija (2012), “The Benefits of R\&D and Breadth in Innovation Strategies: A Comparison of Finnish Service and Manufacturing Firms," Industrial and Corporate Change, Vol. 21, No. 5, pp. 1255-1281.

Levin, Richard C., Alvin K. Klevorick, Richard R. Nelson, and Sidney G. Winter (1987), "Appropriating the Returns from Industrial Research and Development.” Brookings Papers on Economic Activity, No. 3, Special Issue on Microeconomics, pp. 783-820.

Morikawa, Masayuki (2010), “Labor Unions and Productivity: An Empirical Analysis Using Japanese Firm-Level Data,” Labour Economics, Vol. 17, No. 6, pp. 1030-1037. 
Morikawa, Masayuki (2013), “Productivity and Survival of Family Firms in Japan,” Journal of Economics and Business, Vol. 70, November-December, pp. 111-125.

Musolesi, Antonio and Jean-Pierre Huiban (2010), "Innovation and Productivity in Knowledge Intensive Business Services,” Journal of Productivity Analysis, Vol. 34, No. 1 pp. 63-81.

National Institute of Science and Technology Policy (2014), “A Report on the Japanese National Innovation Survey 2012,” NISTEP Report, No. 156.

Nishimura, Kiyohiko G., Takanobu Nakajima, and Kozo Kiyota (2005), "Does the Natural Selection Mechanism Still Work in Severe Recessions? Examination of the Japanese Economy in the 1990s,” Journal of Economic Behavior and Organization, Vol. 58, No. 1, pp. 53-78.

OECD (2005), Oslo Manual: Guidelines for Collecting and Interpreting Innovation Data, 3rd Edition.

Rockett, Katharine (2010), "Property Rights and Invention,” in Bronwyn H. Hall and Nathan Rosenberg eds. Handbook of the Economics of Innovation, Vol. 1, Amsterdam: Elsevier, Ch. 7, pp. 316-380.

Timmer, Marcel P., Robert Inklaar, Mary O’Mahony, and Bart van Ark (2011), "Productivity and Economic Growth in Europe: A Comparative Industry Perspective," International Productivity Monitor, No.21, pp.3-23.

Yamauchi, Isamu, Kazuma Edamura, Yoko Furusawa, and Takamasa Suzuki (forthcoming), "Effects of Strategic IP Management and Early Patent Protection on the SME's Innovation Performance,” ERIA Research Project Report 2012-13. 
Table 1 Summary Statistics

\begin{tabular}{|c|c|c|c|c|c|}
\hline Variables & Nobs. & mean & sd & $\min$ & $\max$ \\
\hline \multicolumn{6}{|c|}{ A. Full sample } \\
\hline patent & 3,444 & 0.232 & 0.422 & 0 & 1 \\
\hline secret & 3,056 & 0.328 & 0.470 & 0 & 1 \\
\hline firm size & 3,198 & 5.245 & 1.031 & 3.912 & 11.249 \\
\hline firm age & 3,198 & 44.726 & 19.456 & 1 & 168 \\
\hline \multicolumn{6}{|c|}{ B. Manufacturing firms } \\
\hline patent & 1,567 & 0.392 & 0.488 & 0 & 1 \\
\hline secret & 1,402 & 0.330 & 0.470 & 0 & 1 \\
\hline firm size & 1,567 & 5.084 & 0.896 & 3.912 & 11.249 \\
\hline firm age & 1,567 & 48.669 & 18.343 & 1 & 168 \\
\hline \multicolumn{6}{|c|}{ C. Service firms } \\
\hline patent & 1,860 & 0.098 & 0.297 & 0 & 1 \\
\hline secret & 1,640 & 0.326 & 0.469 & 0 & 1 \\
\hline firm size & 1,614 & 5.407 & 1.127 & 3.912 & 10.546 \\
\hline firm age & 1,614 & 40.877 & 19.708 & 1 & 106 \\
\hline
\end{tabular}

Notes: Firm size is the natural logarithm of employment. The sum of the manufacturing firms and the service firms is not same as the number of firms in the full sample because a small number of firms do not belong to either the manufacturing industry or the service industry.

Table 2 Innovations of Manufacturing and Service Firms

\begin{tabular}{|l|r|r|r|}
\hline & Manufacturing & \multicolumn{1}{c|}{ Service } & \multicolumn{1}{c|}{ diff. } \\
\hline Entry into new businesses & $15.2 \%$ & $23.6 \%$ & $8.4 \%$ \\
\hline $\begin{array}{l}\text { Development of new } \\
\text { products/services }\end{array}$ & $48.6 \%$ & $36.5 \%$ & $-12.1 \% * * *$ \\
\hline $\begin{array}{l}\text { Improvement of existing } \\
\text { products/services }\end{array}$ & $47.5 \%$ & $33.8 \%$ & $-13.7 \% * * *$ \\
$\begin{array}{l}\text { Adoption of new production or } \\
\text { delivery methods }\end{array}$ & $19.8 \%$ & $16.0 \%$ & $-3.7 \% * * *$ \\
\hline
\end{tabular}

Note: $* * *, * *$, and $*$ indicate the statistically significant differences between manufacturing and service industries at the $1 \%, 5 \%$, and $10 \%$ level, respectively. 
Table 3 Innovations and TFP

\begin{tabular}{|c|c|c|c|c|c|c|}
\hline & \multicolumn{2}{|c|}{ (1) Full sample } & \multicolumn{2}{|c|}{ (2) Manufacturing } & \multicolumn{2}{|l|}{ (3) Service } \\
\hline Entry into new businesses & 0.0244 & & 0.0001 & & 0.0009 & \\
\hline $\begin{array}{l}\text { Development of new } \\
\text { products/services }\end{array}$ & 0.0614 & $* * *$ & 0.0558 & $* *$ & 0.1172 & $* * *$ \\
\hline $\begin{array}{l}\text { Improvement of existing } \\
\text { products/services }\end{array}$ & 0.0866 & $* * *$ & 0.1007 & $* * *$ & 0.1258 & $* * *$ \\
\hline $\begin{array}{l}\text { Adoption of new production } \\
\text { or delivery methods }\end{array}$ & 0.0373 & & 0.0913 & $* * *$ & 0.0016 & \\
\hline
\end{tabular}

Notes: The figures are the differences in TFP level between firms with and without innovations. ***, **, and * indicate the statistically significant differences at the $1 \%, 5 \%$, and $10 \%$ level, respectively.

Table 4 Percentage of Firms Holding Patents and Trade Secrets

\begin{tabular}{|c|c|c|c|c|}
\hline & Manufacturing & Service & diff. & \\
\hline A. Full sample & $(1,402)$ & $(1,640)$ & & \\
\hline Patent & $39.2 \%$ & $9.8 \%$ & $-29.5 \%$ & $* * *$ \\
\hline Trade secret & $33.0 \%$ & $32.6 \%$ & $-0.4 \%$ & \\
\hline B. R\&D performing firms & $\overline{(746)}$ & $(284)$ & & \\
\hline Patent & $60.4 \%$ & $34.8 \%$ & $-25.6 \%$ & $* * *$ \\
\hline Trade secret & $39.3 \%$ & $49.6 \%$ & $10.4 \%$ & $* * *$ \\
\hline C. Non-R\&D performing firms & $(656)$ & $(1,356)$ & & \\
\hline Patent & $15.4 \%$ & $4.7 \%$ & $-10.7 \%$ & $* * *$ \\
\hline Trade secret & $25.8 \%$ & $29.0 \%$ & $3.2 \%$ & \\
\hline
\end{tabular}

Notes: The figures in parentheses are the number of sample firms. The R\&D-performing firms are firms with positive R\&D expenditures during the three fiscal years between 2009 and 2011. 
Table 5 Probit Estimation Results on the Relationship between Patents/Trade Secrets and Innovative Activities

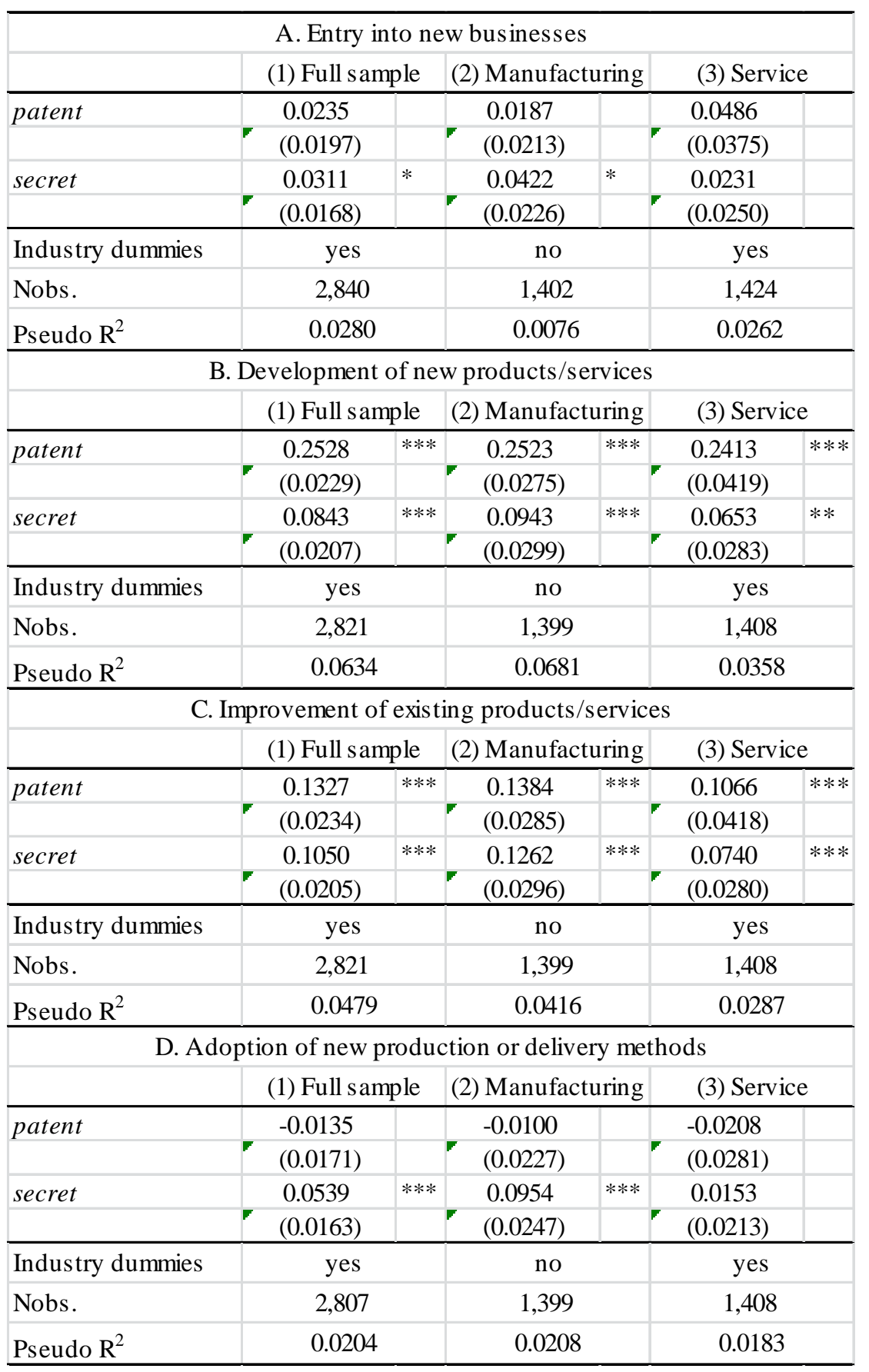

Notes: Probit estimation results with robust standard errors are in parentheses. ***, **, and * indicate significance at the 1\%, 5\%, and 10\% levels, respectively. Explanatory variables include firm size and firm age (the estimate coefficients are not reported in this table). 
Table 6 Probit Estimation Results with an Interaction Term of Patents and Trade Secrets

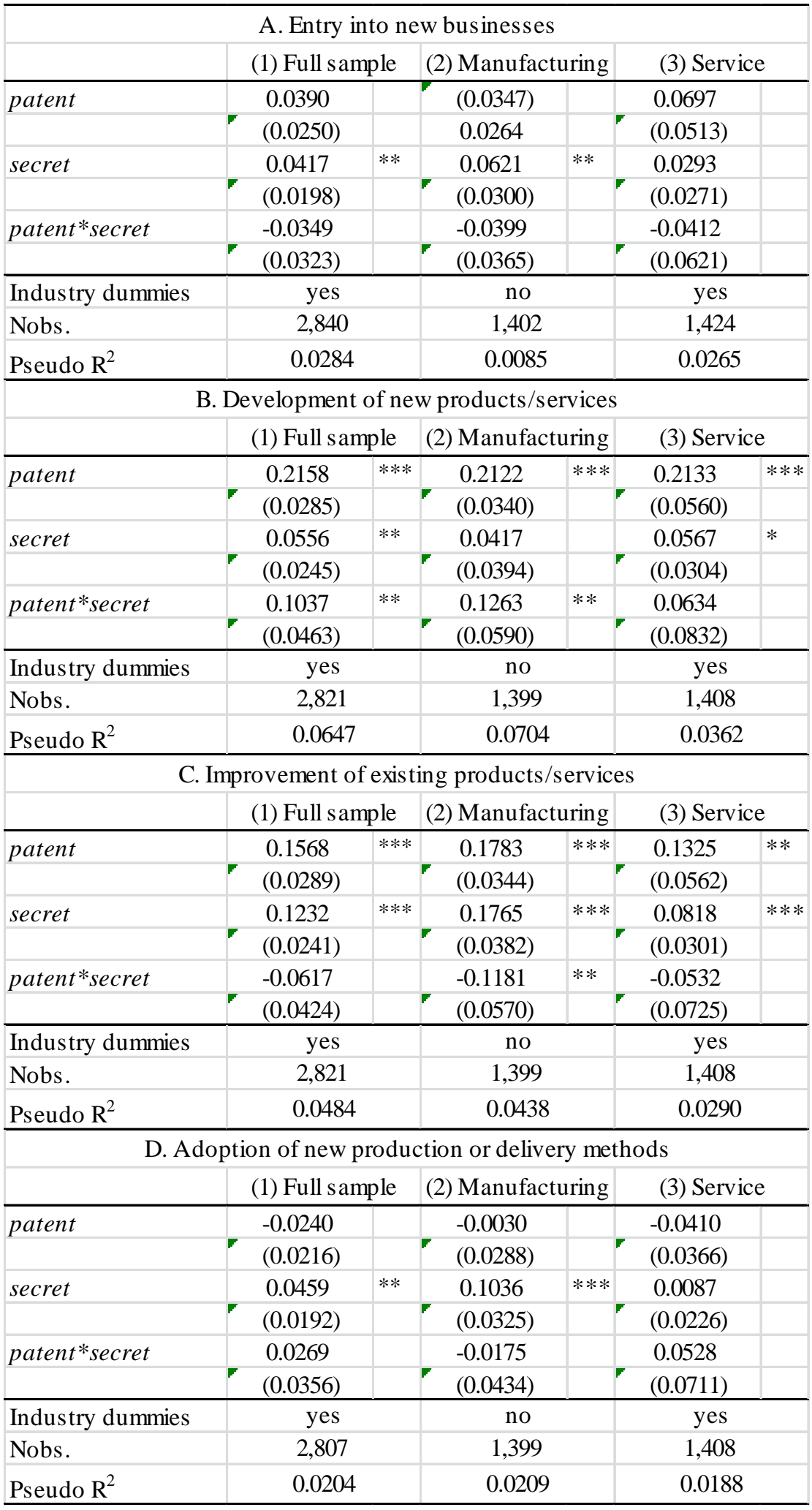

Notes: Probit estimation results with robust standard errors are in parentheses. ***, **, and * indicate significance at the 1\%, 5\%, and 10\% levels, respectively. Explanatory variables include firm size and firm age (the estimate coefficients are not reported in this table). 